RESEARCH ARTICLE

\title{
Comparative Morphological Assessment of Lemongrass (Cymbopogon spp.) Cultivars for Oil yield, Chemical Composition and Quality Parameters under Southern region of India
}

\author{
Yogendra N D ${ }^{1 *}$, Nazeer M $^{1}$, Eresha ${ }^{1}$, Manoj Kumar Yadav ${ }^{2}, K$ Baskaran ${ }^{1}$, V S Pragadheesh ${ }^{1}$, Jnanesha A C ${ }^{3}$ \\ and KVN Satya Srinivas ${ }^{3}$ \\ ${ }^{1}$ CSIR - Central Institute of Medicinal and Aromatic Plants, Research Centre, Bangalore-560065, India \\ ${ }^{2}$ CSIR - Central Institute of Medicinal and Aromatic Plants, Research Centre, Lucknow-226015, India \\ ${ }^{3}$ CSIR-Central Institute of Medicinal and Aromatic Plants, Research Centre, Boduppal, Hyderabad-500092, India
}

\begin{abstract}
Lemongrass (Cymbopogon flexuosus) is an important perennial aromatic plant and natural source of citral that is used in the preparations of variousperfumes.In the present study, eight lemongrass cultivars were evaluated for growth, herbage, and essential oil yield during 2018-2019 inthe southern region of Karnataka, India. Results revealed that significant differences were noticed in the growth and yield parameters of eight lemongrass cultivars studied. The plant height and the number of tillers varies, ranging from $108.47-136.75 \mathrm{~cm}$ and $38.13-47.60$, respectively. Significantly higher herbage yield ( $\mathrm{t} / \mathrm{ha}$ /year) was recorded in CIM-Shikar (24.25), followed by Krishna (22.50) and CKP-25 (20.72). The lowest herbage yield wasrecorded in the Cauvery cultivar. Essential oil content varied from $0.70-1.35 \%(\mathrm{v} / \mathrm{w})$ and essential oil yield varies from $133.56-302.40 \mathrm{~kg} / \mathrm{ha} /$ year in different cultivars. The amount of citral varied from $2.20 \%$ to $88.14 \%$ among eight lemongrass cultivars. The varieties arranged according to the citral content as follows, Cauvery $(88.84 \pm 0.99)>$ Nima $(88.57 \pm 0.70)$ $>$ CIM-Shikar $(84.97 \pm 4.08)>0 D-19(85.90 \pm 0.59)>$ CIM-Suvarna $(82.53$ $\pm 1.10)>$ CKP-25 $(81.84 \pm 0.30)>$ Krishna $(79.26 \pm 0.44)>$ CIM-Atal $(2.15$ $\pm 0.07)$. CIM-Atal was superior in geraniol $(88.92 \pm 1.00 \%)$ compared to citral (geranial and neral) content among lemongrass cultivars studied; this cultivar may be a partial replacement/ substitute for geraniol rich essential oil-bearing plant in the future. Overall, cultivar CIM-Shikar was superior to other cultivars in terms of essential oil yield $(302.40 \mathrm{~kg} / \mathrm{ha} / \mathrm{year})$ and superior in citral content $(84.97 \pm 4.08)$.
\end{abstract}

Keywords:Citral content; Essential oil content; Herbage and oil yield; Lemongrass cultivars

\section{INTRODUCTION}

Lemongrass (Cymbopogon flexosus, Family: Poaceae) is an important perennial aromatic grass with enormous pharmaceuticaland industrial demand, broadly distributed throughout the world and particularly in tropical and subtropical nations (Francisco et al., 2011). Leaves of lemongrass plants are commonly used in thepreparation of herbal teas and also have wide applications in food preparations. The essential oil has wide application in flavor and fragrance, pharmaceutical, aromatherapy (Shioda, 2014) and pesticide industries (Zhang et al.,2016; Antonioli et al.,2020). Lemongrass essential oil ranks in the top ten among the essential oil-bearing crops in the world mainly because of its commercial value and wide applications (Ravinder et al., 2010). The main chemical constituent of lemongrass is citral ${ }^{*}$ Corresponding author's e-mail: yogendra.nd@cimap.res.in (geranial and neral) comprises more than $70-80 \%$ and it is one of the very important molecules involved in several chemical syntheses (Negrelle and Gomes, 2007). For synthesis of $\alpha$-and $\beta$-ionones, citral is a base material, $\alpha$-ionone is used in cosmetic, flavors and perfume, for vitamin ' $A$ ' synthesis $\beta$-iononeis used (Thappa et al., 1981).

There aremore than 140 species in the genus Cymbopogon (Kumari et al., 2007), out of which 45 are grown in India, and lemongrass is commercially important for the production of essential oil (Hassan et al., 2007). The Cymbopogon spp. have a unique character, that they can be cultivated in different types of soils even with less fertile status of the land and have good adaptability to diverse agro-climatic conditions. The most commonly cultivated and 
economic species of Cymbopogon are C. nardus, C. flexuosus, C. pendulus, C. citratus, C. khasianus, C. martini, C. winterianus, and C. jwarancusa, yields essential oils which are having commercial value viz.,lemongrass oil, citronella oil, palmarosa oil, ginger grass (Gupta and Jain, 1978; Rao 1997; Kumar et al., 2000). More than 60000 hectares area is under cultivation of aromatic grasses in India distributed in different states viz., Madhya Pradesh, Gujarat, Karnataka, Assam, Kerala, Maharashtra, Uttar Pradesh and Andhra Pradesh (Husain, 1994; Padalia et al., 2011).

The total demandfor lemongrass oil in the world is rising, and it's about 500 tonnes. However, its production is only about 300 tonnes; India is one of the major producers of lemongrass oil to the extent of about 200 tonnes, about 90 tonnes is exported (Singh et al., 2009). Therefore, the crop was gaining popularity due to the enormous scope and demand arising from lemongrass oil industries, leading to research and development activities for the selection of superior cultivars. There is an immediate need for the developmentof high-yielding essential oilbearing cultivars and pressure on arable lands for its commercial cultivation to meet the world demand in the coming days. For profitable cultivation aspects of lemongrass, the assortment procedure depends upon the breeding plant with traits like plant height, tiller numbers, leaf area, herbage yield oil yield and citral content of the cultivar(Nair, 1982). Considering these points, eight lemongrass cultivars were evaluated in the southern region of Karnataka, India.

\section{MATERIALS AND METHODS Experimental location}

The field experiment was conductedat CSIRCentral Institute of Medicinal, and Aromatic Plants, Research Centre, Bengaluru with eight lemongrass cultivars that were released by CIMAP. The location comes under southern region of Karnataka, with an altitude of $930 \mathrm{~m}$ above the MSL. The latitude and longitude of the zone $\mathrm{N}: 13.085$ and longitude of E: 77.592 , respectively, received an annual rainfall of about $925 \mathrm{~mm}$ during2018 (Figure 1). The soil characteristics of the experimental site are presented in Table 1.

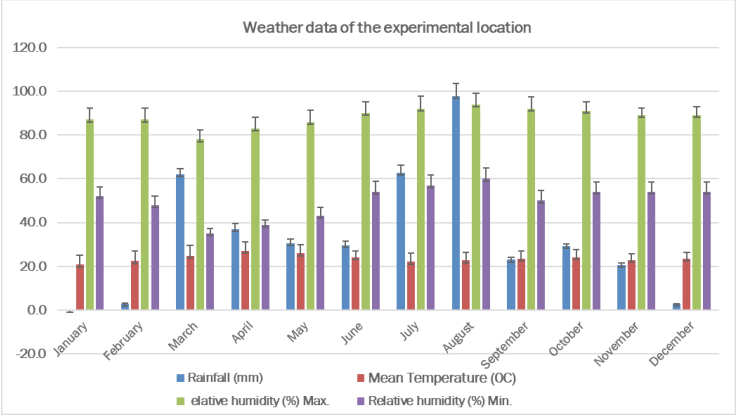

Figure 1. Monthly average temperature and rainfall condition of the experimental area during 2018-2019
Table 1. Initial soil characteristics of lemongrass experimental site

\begin{tabular}{|c|c|}
\hline Particulars & Values \\
\hline \multicolumn{2}{|l|}{ A. Physical properties } \\
\hline \multicolumn{2}{|c|}{$\begin{array}{l}\text { Particle size distribution } \\
\end{array}$} \\
\hline Sand (\%) & 66.65 \\
\hline Silt (\%) & 22.89 \\
\hline Clay (\%) & 9.65 \\
\hline Textural class & Sandy loam \\
\hline \multicolumn{2}{|l|}{ B. Chemical properties } \\
\hline $\mathrm{pH}(1: 2.5)$ & 7.25 \\
\hline $\mathrm{EC}\left(\mathrm{dSm}^{-1}\right)$ & 0.65 \\
\hline $\mathrm{OC}(\%)$ & 0.65 \\
\hline $\operatorname{CEC}\left(\mathrm{C} \mathrm{mol}\left(\mathrm{P}^{+}\right) \mathrm{kg}^{-1}\right.$ & 11.75 \\
\hline Available N (kg ha-1) & 292.50 \\
\hline Available $\mathrm{P}_{2} \mathrm{O}_{5}\left(\mathrm{~kg} \mathrm{ha}^{-1}\right)$ & 21.75 \\
\hline Available $\mathrm{K}_{2} \mathrm{O}\left(\mathrm{kg} \mathrm{ha}^{-1}\right)$ & 90.53 \\
\hline Available S (ppm) & 9.55 \\
\hline Exchangeable $\mathrm{Ca}\left(\mathrm{C} \mathrm{mol} \mathrm{P}^{(+)} \mathrm{kg}^{-1}\right)$ & 1.45 \\
\hline Exchangeable $\mathrm{Mg}\left(\mathrm{C}\right.$ mol $\left.\mathrm{P}^{(+)} \mathrm{kg}^{-1}\right)$ & 1.30 \\
\hline Available Fe (ppm) & 16.58 \\
\hline Available Zn (ppm) & 1.75 \\
\hline Available Cu (ppm) & 1.76 \\
\hline Available Mn (ppm) & 16.85 \\
\hline
\end{tabular}

\section{Experimental details}

A Randomized Complete Block Design (RCBD) was adopted to carry out the experiment in the field with eight lemongrass cultivars which were replicated thrice. The experimental plot size was $3.6 \mathrm{~m} \times 3.6 \mathrm{~m}$ with $45 \mathrm{~cm}$ spacing between rowto-row and plant-to-plant. RDF (Recommended dose of fertilizers) 150:40:40 kg/ha N, $\mathrm{P}_{2} \mathrm{O}_{5}, \mathrm{~K}_{2} \mathrm{O}$, respectively, were applied to the soil on the planting day. The top dressing was done with $75 \% \mathrm{~N}$ with four equal splits. The crop was irrigated whenever there was a need.

\section{Observations}

Five randomly selected healthy plants were selected and tagged for observations. The plant height was measuredduring the time of harvest with a meter scale.The number of tillers per clump and the number of leaves per tillers, were recorded by counting manually. Yield parameters viz., herbage yield, and essential oil yield was calculated based on the net plot yield and converted to tone per hectare.

\section{Source of different lemongrass cultivars}

Different Cymbopogon spp. (viz., OD-19, CKP25, Cauvery, Nima, CIM-Suvarna, Krishna and CIM-Shikar) evaluated in the present study were collected from CSIR-CIMAP, Research Centre, Bengaluru, lemongrass gene bank. The gene bank was properly maintained from its initiation in the 
same piece of land with proper isolation distance and proper care was taken to avoid add mixtures of the other cultivars. Whereas, CIM-Atal geraniol rich lemongrass cultivar was recently released by CSIR-CIMAP in 2019, which was developed from Bengaluru Research Centre. The source and year of release of cultivars and other information are provided in Table 2, and their visual physical identical and morphological characteristics are provided in Table 3.

Table 2. General information of different cultivars of lemongrass (Cymbopogon spp.).

\begin{tabular}{|c|c|c|c|c|}
\hline Cultivars & Plant species & Variety Development & Adaptability & $\begin{array}{l}\text { Cultivar details } \\
\text { references }\end{array}$ \\
\hline Krishna & Cymbopogon. flexuosus & Clonal selection & Indian Plains and hills & Anonymous (1997) \\
\hline Cauvery & Cymbopogon. flexuosus & $\begin{array}{l}\text { Phenotypic recurrent } \\
\text { selection }\end{array}$ & $\begin{array}{l}\text { Requires high soil moisture and is evolved } \\
\text { for river valley tracts of Indian Plains }\end{array}$ & Patra et al (2005) \\
\hline Nima & Cymbopogon. flexuosus & $\begin{array}{l}\text { Half-sib seed followed } \\
\text { by clonal selection }\end{array}$ & Indian Plains & Anonymous (2003) \\
\hline OD-19 & Cymbopogon. flexuosus & Clonal selection & $\begin{array}{l}\text { Adapted to a wide range of soil and } \\
\text { climatic condition. much suited for rained } \\
\text { cultivation }\end{array}$ & Kumar et al (2000) \\
\hline CIM-Suwarna & Cymbopogon. khasianus & Clonal selection & Drought prone areas and marginal lands & Lal et al (2010) \\
\hline CIM Shikar & Cymbopogon. flexuosus & Recurrent selection & High yielding cultivar (>20\% Krishna) & Anonymous, (2016) \\
\hline CKP-25 & C. khasianus $\times$ C. pendulus & Hybridization & Grows well in northern plains & Rao and Sobti, (1991) \\
\hline ClM-Atal & Cymbopogon. flexuosus & Selection & $\begin{array}{l}\text { Geraniol rich ( } 80-85 \%) \text { grows well in } \\
\text { tropical and subtropical region }\end{array}$ & Kulkarni et al (2020) \\
\hline
\end{tabular}

\section{ANALYTICAL METHODS}

\section{Extraction of the essential oil:}

The fresh leaves (100 g) of each cultivar of lemongrass (Cymbopogon spp.) were collected and subjected to hydrodistillation for 3 hours in a
Clevenger-type apparatus to extract essential oil. The oils samples were dehydrated with anhydrous $\mathrm{Na}_{2} \mathrm{SO}_{4}$ and kept in a cool, dark place until further analysis.

Table 3. Comparative analysis of physical parameters of different lemongrassflexuosus

\begin{tabular}{|c|c|c|c|c|c|c|c|c|c|}
\hline \multicolumn{2}{|c|}{ Cultivars } & Krishna & Suwarna & OD-19 & Neema & Cauvery & CKP-25 & $\begin{array}{c}\text { CIM- } \\
\text { Shikar }\end{array}$ & CIM-Atal \\
\hline \multicolumn{10}{|c|}{$\begin{array}{ll}\text { Characteristics } \\
\end{array}$} \\
\hline Habit & & Semi pendent & Erect straight & $\begin{array}{l}\text { Erect } \\
\text { straight }\end{array}$ & $\begin{array}{l}\text { Erect } \\
\text { straight }\end{array}$ & $\begin{array}{l}\text { Semi } \\
\text { pendent }\end{array}$ & $\begin{array}{l}\text { Erect } \\
\text { straight }\end{array}$ & $\begin{array}{l}\text { Erect } \\
\text { straight }\end{array}$ & $\begin{array}{l}\text { Erect } \\
\text { straight }\end{array}$ \\
\hline \multirow[t]{2}{*}{ Height(cms) } & 1)Vegetative & 75 & 81 & 80 & 73 & 72 & 77 & 73 & 79 \\
\hline & 2)Matured & 128 & 132 & 127 & 115 & 126 & 109 & 130 & 125 \\
\hline \multirow[t]{2}{*}{ Colour } & 1)Stalk/Culm & Light brown & Light yellow & $\begin{array}{l}\text { Dark } \\
\text { brown }\end{array}$ & $\begin{array}{l}\text { Reddish } \\
\text { brown }\end{array}$ & $\begin{array}{l}\text { Reddish } \\
\text { brown }\end{array}$ & $\begin{array}{l}\text { Light } \\
\text { purple }\end{array}$ & $\begin{array}{l}\text { Reddish } \\
\text { brown }\end{array}$ & $\begin{array}{l}\text { Reddish } \\
\text { brown }\end{array}$ \\
\hline & 2)Leaf sheath & $\begin{array}{l}\text { Reddish } \\
\text { brown }\end{array}$ & Light purple & $\begin{array}{l}\text { Reddish } \\
\text { brown }\end{array}$ & $\begin{array}{l}\text { Light } \\
\text { purple }\end{array}$ & $\begin{array}{l}\text { Light } \\
\text { purple }\end{array}$ & $\begin{array}{l}\text { Light } \\
\text { yellow }\end{array}$ & $\begin{array}{l}\text { Light } \\
\text { purple }\end{array}$ & $\begin{array}{l}\text { Light } \\
\text { purple }\end{array}$ \\
\hline $\begin{array}{l}\text { Supressed } \\
\text { internodes }\end{array}$ & 1)Number & 8 & 7 & 7 & 7 & 7 & 6 & 6 & 6 \\
\hline \multirow[t]{2}{*}{ Length(cms) } & 1)Ligule & 0.4 & 0.3 & 0.2 & 0.4 & 0.2 & 0.3 & 0.3 & 0.2 \\
\hline & 2)Auricle & 0.3 & 0.2 & 0.3 & 0.3 & 0.4 & 0.2 & 0.3 & 0.4 \\
\hline Leaf area(cm2) & $\begin{array}{l}\text { Avg. of } 5 \\
\text { leaves }\end{array}$ & 1.54 & 1.2 & 1.42 & 2.3 & 1.38 & 1.2 & 1.38 & 1.3 \\
\hline Tiller Number & & 55 & 53 & 46 & 45 & 38 & 48 & 58 & 55 \\
\hline $\begin{array}{l}\text { Inter nodal } \\
\text { distance }\end{array}$ & & 1.6 & 1.4 & 2.3 & 1.3 & 3.2 & 0.9 & 2.5 & 2.1 \\
\hline $\begin{array}{l}\text { Shoot initiation } \\
\text { Point(cms) }\end{array}$ & & 20 & 15 & 14.8 & 13 & 20 & 11 & 21 & 23 \\
\hline $\begin{array}{l}\text { Number of } \\
\text { Leaves }\end{array}$ & & 5 & 5 & 5 & 4 & 3 & $3-4$ & 5 & 5 \\
\hline \multirow[t]{2}{*}{ Midrib(cms) } & $\begin{array}{l}\text { 1)Right side } \\
\text { region }\end{array}$ & 0.6 & 0.5 & 0.7 & 0.9 & 0.6 & 0.5 & 0.7 & 0.5 \\
\hline & $\begin{array}{l}\text { 2)Left side } \\
\text { region }\end{array}$ & 0.5 & 0.4 & 0.6 & 1.0 & 0.4 & 0.5 & 0.7 & 0.5 \\
\hline
\end{tabular}




\section{GC Method:}

Gas chromatographic analysis was performed on an Agilent 7890B gas chromatograph equipped with a flame ionization detector. For separation, an Agilent HP-5 column of 30 m length, $320 \mu \mathrm{m}$ internal diameter, and $0.25 \mu \mathrm{m}$ film thickness was used. Samples were injected into a split/splitless inlet maintained at a temperature of $250^{\circ} \mathrm{C}$ with a split ratio of 1:35. Nitrogen was used as a carrier gas with $2 \mathrm{~mL} / \mathrm{min}$ constant flow rate. The column oven temperature, was programmed from $60^{\circ} \mathrm{C}$ and increased at the rate of $3^{\circ} \mathrm{C} / \mathrm{min}$ till $240^{\circ} \mathrm{C}$ and held at $240^{\circ} \mathrm{C}$ for $2 \mathrm{~min}$. The FID detector temperature was kept at $280^{\circ} \mathrm{C}$.

\section{GC-MS Method:}

Gas chromatography-mass spectrometry analysis was performed on a PerkinEImer Clarus 680 model GC and a SQ 8C MS using an Elite-5MS column of dimensions, $30 \mathrm{~m} \times 0.25 \mathrm{~mm}$ with film thickness of $0.25 \mu \mathrm{m}$. Injector temperature of GC was kept at $290^{\circ} \mathrm{C}$ and Helium as carrier gas with $1 \mathrm{~mL} /$ min constant flow rate with a split ratio of $1: 100$. The column oven was programmed from $60^{\circ} \mathrm{C}$ to $240^{\circ} \mathrm{C}$ at the rate of $3^{\circ} \mathrm{C} / \mathrm{min}$. Samples were transferred from GC to MS through an inter line which was maintained at a temperature of $250^{\circ} \mathrm{C}$. The ionization source of MS was at $250^{\circ} \mathrm{C}$ and the compounds were ionized with an ionization potential of $70 \mathrm{eV}$. The mass spectrometer was programmed to scan in the range of 40 to 450 amu with a scan time of $0.8 \mathrm{sec}$ and an interscan delay of $0.01 \mathrm{sec}$. Compounds were identified by matching the relative retention index calculated using $n$-alkanes, $\left(C_{7}-C_{30}\right.$ hydrocarbons) and confirmed by comparing the mass spectrum of the compounds with themass spectral library.

\section{RESULTS AND DISCUSSION}

The growth and yield parameters of different cultivars of lemongrass are presented in Table 4. Growth traits of lemongrass varied significantly due to the different cultivars studied. The significantly higher plant height was noticed in CIM-Shikar $(136.75 \mathrm{~cm})$, followed by CIM-Suwarna $(131 \mathrm{~cm})$, and the lowest plant height was noticed in Cauvery. A higher number of tillers per clump was noticed in CIM-Shikar (47.60) followed by Krishna (47.53) and CKP-25 (42.13). A lesser number of tiller per clump was noticed in Nima (38.13) cultivar. This difference in the number of tillers is mainly due to dissimilarity in the inherited characters of the genotypes and variations in the environmental conditions (Singh and Singh, 1999, Sharma et al.,2005, Ibrahim and Khalidh, 2013). Similarly, results are in agreement with the findings of Lal et al. (2006), who reported plant height in the range of $100-160 \mathrm{~cm}$ and the number of tillers/plant in the range of 45-65 for four elite clones of lemongrass. However, there was no significant difference in the number of leaves per tillers among the cultivars studied.Allard (1960) and PoehIman and Sleper (1995) reported thatincidence of variation in plants occurs due to hereditary differences in the plant and environmental conditions where plants are grown or sometimes combination of both.

Table 4. Growth and yield parameters of eight different lemongrass cultivars

\begin{tabular}{|c|c|c|c|c|c|c|}
\hline Cultivar & Plant height (cm) & $\begin{array}{c}\text { Number tillers/ } \\
\text { clump }\end{array}$ & $\begin{array}{c}\text { Number of leaves } \\
\text { per tiller }\end{array}$ & $\begin{array}{c}\text { Herbageyield ( } t / \\
\text { ha/year)* }\end{array}$ & $\begin{array}{c}\text { Oil recovery } \\
(\%)\end{array}$ & $\begin{array}{c}\text { Oil yield }(\mathrm{kg} / \mathrm{ha} / \\
\text { year) }\end{array}$ \\
\hline Krishna & 128.87 & 47.53 & 5.08 & 22.50 & 1.20 & 269.98 \\
\hline Cauvery & 108.47 & 39.53 & 5.08 & 17.85 & 0.85 & 151.44 \\
\hline Nima & 111.73 & 38.13 & 5.25 & 18.35 & 0.90 & 164.90 \\
\hline OD-19 & 123.85 & 41.20 & 4.85 & 19.05 & 0.70 & 133.56 \\
\hline CIM-Suvarna & 131.00 & 39.20 & 5.17 & 19.35 & 1.15 & 223.17 \\
\hline CIM-Shikar & 136.75 & 47.60 & 5.65 & 24.25 & 1.25 & 302.40 \\
\hline CKP-25 & 115.87 & 42.13 & 4.93 & 20.72 & 1.20 & 247.82 \\
\hline CIM-Atal & 122.87 & 40.67 & 5.45 & 20.35 & 1.35 & 275.44 \\
\hline $\mathrm{SEm} \pm$ & 1.28 & 1.59 & 0.37 & 1.28 & 0.04 & 18.07 \\
\hline CD at $5 \%$ & 3.89 & 4.83 & NS & 3.88 & 0.13 & 54.80 \\
\hline
\end{tabular}

*Harvest at 8months and 20 days second harvest was takeninto account

The herbage and oil yield differed significantly due to different cultivars and yield attributing characters of lemongrass. The herbage yield ranges from 17.85-24.24 tha ${ }^{-1}$. The higher herbage yield was recorded in cultivar CIM-Shikar (24.25 tha $\left.{ }^{1}\right)$, followed by Krishna $\left(22.50\right.$ tha $\left.^{-1}\right)$ and CKP-25 (20.72 tha $\left.{ }^{-1}\right)$; conversely, cultivar Cauvery showed the lowest herbage yield $\left(17.85\right.$ tha $\left.^{-1}\right)$ among all the cultivars evaluated in the present study. The recovery of essential oil ranges from $0.70 \%$ to $1.35 \%$.The highest recovery was recorded in CIM-Atal (1.35\%) followed by CIM-Shikar (1.25\%) and the lowest was noticed in OD-19 (0.70\%). Sarma and Sarma,(2005) reported that oil recovery range from $0.55-1.03 \%$ for lemongrass collections cultivated in Northeast Indian climatic circumstances. Similarly, the higher essential oil yield was recorded in cultivar CIMShikar(302.40 kg/ha/year), followed by CIM-Atal

$108|1-3| 4$ 
(275.44 kgha $^{-1}$ year $\left.^{-1}\right)$ and Krishna (269.98 kg ha ${ }^{-1}$ year ${ }^{-1}$ ), whereas cultivar OD-19 (133.56 kg ha-1 year $\left.{ }^{1}\right)$ recorded lower essential oil yield. The increase in the herbage yield and essential oil yield maybe due to the production of more tillers per plant, the number of leaves/tillers, plant height had a positive and strong correlation/association with yield parameters (Table 6). Verma et al. (2015) reported that cultivar Krishna recorded higher amounts of essential oil (2.35 L per $100 \mathrm{~m}^{2}$ ) with $80.70 \%$ of citral among eight lemongrasses evaluated under the Himalayan region of India.

Table 5. Chemical composition of lemongrass cultivars

\begin{tabular}{|c|c|c|c|c|c|c|}
\hline Cultivar & Geranial & Neral & Citral* & Geraniol & Geranyl acetate & G/N ratio \\
\hline Krishna & $47.38 \pm 0.42$ & $31.88 \pm 0.01$ & $79.26 \pm 0.44$ & $6.43 \pm 0.18$ & $1.98 \pm 0.13$ & $1.49 \pm 0.01$ \\
\hline Cauvery & $51.47 \pm 0.58$ & $37.37 \pm 0.41$ & $88.84 \pm 0.99$ & $0.61 \pm 0.04$ & $0.12 \pm 0.01$ & $1.38 \pm 0.00$ \\
\hline Nima & $51.94 \pm 0.49$ & $36.63 \pm 0.21$ & $88.57 \pm 0.70$ & $0.76 \pm 0.21$ & $0.31 \pm 0.08$ & $1.42 \pm 0.01$ \\
\hline OD-19 & $52.78 \pm 1.52$ & $33.12 \pm 2.11$ & $85.90 \pm 0.59$ & $1.22 \pm 0.10$ & $0.51 \pm 0.22$ & $1.60 \pm 0.15$ \\
\hline CIM-Suvarna & $46.94 \pm 0.71$ & $35.59 \pm 0.40$ & $82.53 \pm 1.10$ & $2.78 \pm 0.01$ & $3.02 \pm 0.13$ & $1.32 \pm 0.00$ \\
\hline CIM-Shikar & $50.79 \pm 1.48$ & $34.18 \pm 2.60$ & $84.97 \pm 4.08$ & $3.76 \pm 3.30$ & $2.14 \pm 2.28$ & $1.49 \pm 0.07$ \\
\hline CKP-25 & $48.84 \pm 0.18$ & $33.00 \pm 0.13$ & $81.84 \pm 0.30$ & $3.15 \pm 0.30$ & $2.13 \pm 0.06$ & $1.48 \pm 0.00$ \\
\hline CIM-Atal & $1.47 \pm 0.02$ & $0.80 \pm 0.07$ & $2.15 \pm 0.07$ & $88.92 \pm 1.00$ & $2.50 \pm 0.03$ & $1.84 \pm 0.13$ \\
\hline
\end{tabular}

*Citral = geranial + neral, G/N ratio : geranial/neral

With concern to the chemical composition of lemongrass cultivars studied in the present study, geranial was recorded highest $(52.78 \pm 1.52 \%)$ in OD-19, followed by Nima (51.94 \pm 0.49$)$, and the lowest amount was found in CIM-Atal (1.47 $\pm 0.02 \%)$ cultivar (Table 5, Figure2-9). Similarly, the highest neral content was recorded in cultivar Cauvery (37.37 $\pm 0.41 \%)$ followed by Nima (36.63 $\pm 0.218 \%)$ cultivar. The market acceptability of lemongrass essential oil is determined by the amount of citral which is a combination of two stereo-isomeric monoterpenoid aldehyde compounds namely, geranial (trans isomer) and neral (cis isomer). The amount of geranial and neral constitute the total amount of citral, which is the main compound thatdecides the marketability of lemongrass essential oil. The citral content varies from 2.15$88.84 \%$. The verities arranged according to the citral content as, Cauvery $(88.84 \pm 0.99)>\operatorname{Nima}(88.57 \pm$ $0.70)>$ CIM-Shikar $(84.97 \pm 4.08)>$ OD-19(85.90 \pm 0.59) > CIM-Suvarna $(82.53 \pm 1.10)>$ CKP-25(81.84 $\pm 0.30)>$ Krishna $(79.26 \pm 0.44)>$ CIM-Atal $(2.15$ $\pm 0.07)$. The citral content range between $72-75 \%$ was reported for Indian lemongrass collections by Kumari et al. (2009). A comparatively higher amount of citral (89\%) was stated by Lal et al. (2001) for SEG 49 lemongrass clone; similarly, Ganjewala (2008) reported citral range of $82-88 \%$ for West Indian lemongrass. CIM-Atal cultivars bear low citral content compared to all other cultivars in the present study.

Table 6. Correlation of growth, yield and chemical parameters of different lemongrass cultivars

\begin{tabular}{|c|c|c|c|c|c|c|c|c|c|c|c|c|}
\hline Parameters & $\begin{array}{c}\text { Plant } \\
\text { height }\end{array}$ & $\begin{array}{c}\text { Number } \\
\text { tillers / } \\
\text { clump }\end{array}$ & $\begin{array}{l}\text { Number } \\
\text { of leaves } \\
\text { per tiller }\end{array}$ & $\begin{array}{c}\text { Oil } \\
\text { recovery } \\
(\%)\end{array}$ & $\begin{array}{c}\text { Herbage } \\
\text { yield }\end{array}$ & $\begin{array}{c}\text { Oil } \\
\text { yield }\end{array}$ & Geranial & Neral & Citral & Geraniol & $\begin{array}{l}\text { Geranyl } \\
\text { acetate }\end{array}$ & $\begin{array}{l}\mathrm{G} / \mathrm{N} \\
\text { ratio }\end{array}$ \\
\hline Plant height $(\mathrm{cm})$ & 1.000 & & & & & & & & & & & \\
\hline Number tillers/clump & $0.656 * * *$ & 1.000 & & & & & & & & & & \\
\hline Number of leafs per tiller & $0.437 *$ & $0.283 \mathrm{~ns}$ & 1.000 & & & & & & & & & \\
\hline Oil recovery (\%) & $0.493 *$ & $0.453 *$ & $0.582 * *$ & 1.000 & & & & & & & & \\
\hline Herbage yield & $0.760 * * *$ & $0.928 * * *$ & $0.517 * *$ & $0.670 * * *$ & 1.000 & & & & & & & \\
\hline Oil yield & $0.639 * * *$ & $0.682 * * *$ & $0.621 * * *$ & $0.955 * * *$ & $0.860 * * *$ & 1.000 & & & & & & \\
\hline Geranial & $-0.055 \mathrm{~ns}$ & $0.132 \mathrm{~ns}$ & $-0.377 \mathrm{~ns}$ & $-0.544 \mathrm{~ns}$ & $-0.025 \mathrm{~ns}$ & $-0.389 \mathrm{~ns}$ & 1.000 & & & & & \\
\hline Neral & $-0.060 \mathrm{~ns}$ & 0.070 ns & $-0.346 \mathrm{~ns}$ & $-0.536 \mathrm{~ns}$ & $-0.071 \mathrm{~ns}$ & $-0.401 \mathrm{~ns}$ & $0.993 * * *$ & 1.000 & & & & \\
\hline Citral & $-0.057 \mathrm{~ns}$ & $0.106 \mathrm{~ns}$ & $-0.365 \mathrm{~ns}$ & $-0.542 \mathrm{~ns}$ & $-0.044 \mathrm{~ns}$ & $-0.395 \mathrm{~ns}$ & $0.999 * * *$ & $* 0.998 * * *$ & 1.000 & & & \\
\hline Geraniol & $0.044 \mathrm{~ns}$ & $-0.110 \mathrm{~ns}$ & $0.397 \mathrm{~ns}$ & $0.517 * *$ & $0.039 \mathrm{~ns}$ & $0.378 \mathrm{~ns}$ & $-0.996 \mathrm{~ns}$ & -0.995 ns & $-0.998 \mathrm{~ns}$ & 1.000 & & \\
\hline Geranyl acetate & $0.342 \mathrm{~ns}$ & $0.008 \mathrm{~ns}$ & $0.019 \mathrm{~ns}$ & $0.714 * * *$ & 0.177 ns & $0.550 * *$ & $-0.518 \mathrm{~ns}$ & $-0.488 \mathrm{~ns}$ & $-0.507 \mathrm{~ns}$ & $0.451^{*}$ & 1.000 & \\
\hline $\mathrm{G} / \mathrm{N}$ ratio & $0.032 \mathrm{~ns}$ & $0.029 \mathrm{~ns}$ & $0.306 \mathrm{~ns}$ & $0.455^{*}$ & $0.136 \mathrm{~ns}$ & $0.372 \mathrm{~ns}$ & $-0.933 \mathrm{~ns}$ & $-0.968 \mathrm{~ns}$ & $-0.949 \mathrm{~ns}$ & $0.954 * * *$ & $0.331 \mathrm{~ns}$ & 1.000 \\
\hline
\end{tabular}

${ }^{* * *}$ significance at $P<0.001,{ }^{* *}$ significance at $P<0.01$, ${ }^{*}$ significance at $P<0.5$; ns=non-significant; $P<0.05$ probability level 
CIM-Atal cultivar was mainly bred for high geraniol content purposes rather than citral content. Though, palmarosa (C. martini) crop yields comparatively less oil recovery of about $(0.56 \%)$ with an average oil yield of $139.7 \mathrm{kgha}^{-1}$ comprising geraniol content of about $82.26 \%$ and geranyl acetate approximately 13.05\% under the Himalayan region as reported by Chauhan et al. (2017) whereas CIM-Atal stands superior in comparison with palmarosa crop for geraniol source. This cultivar can be a substitute for geraniol-rich essential oil bearing plant in the future. Further studies are needed address its geraniol content and performance in different seasons and locations for stability.

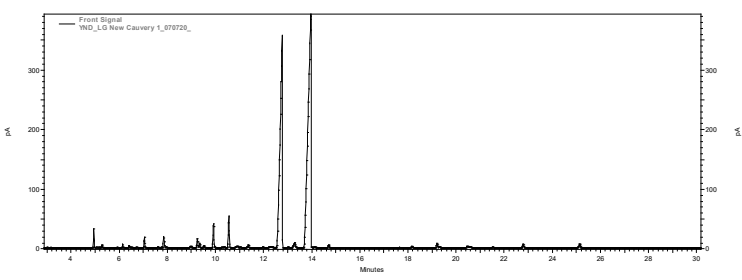

Figure 2. Gas chromatographic profile of the essential oil of cultivar Cauvery

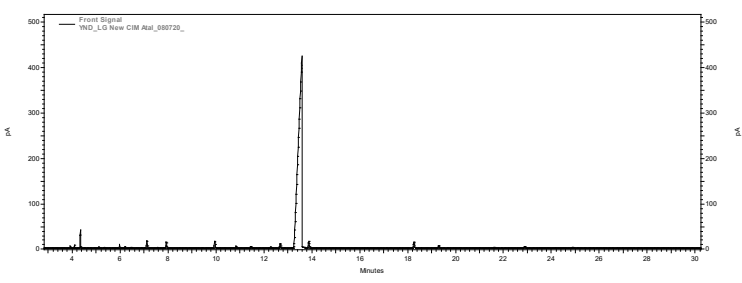

Figure 3. Gas chromatographic profile of the essential oil of cultivar CIM-Atal

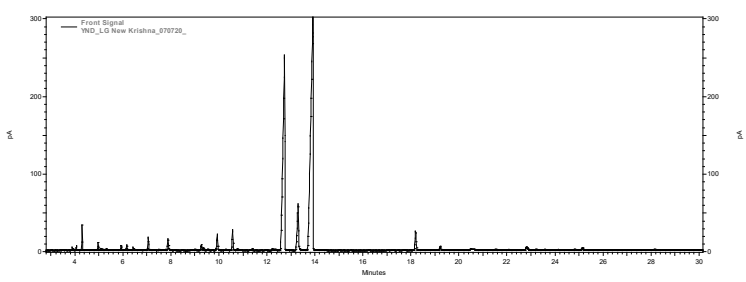

Figure 4. Gas chromatographic profile of the essential oil of cultivar Krishna

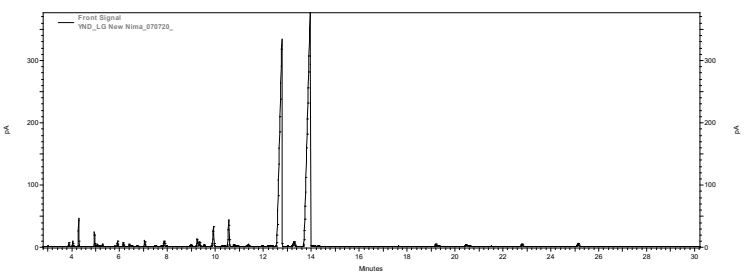

Figure 5. Gas chromatographic profile of the essential oil of cultivar Nima

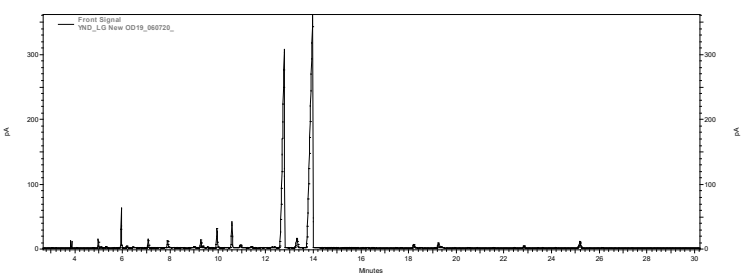

Figure 6. Gas chromatographic profile of the essential oil of cultivar OD-19

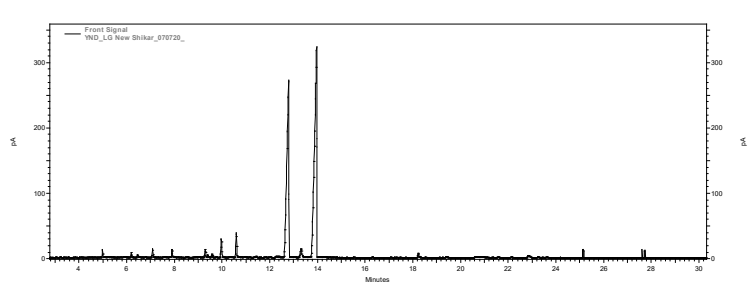

Figure 7. Gas chromatographic profile of the essential oil of cultivar CIM-Shikar

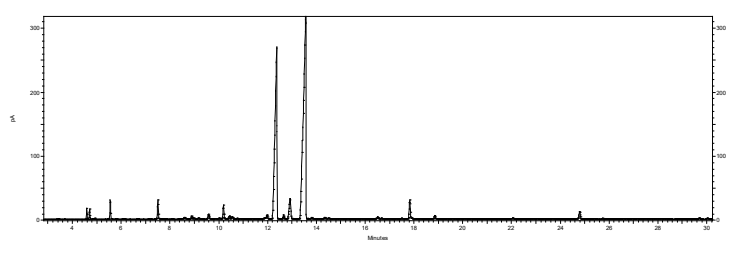

Figure 8. Gas chromatographic profile of the essential oil of cultivar CKP-25

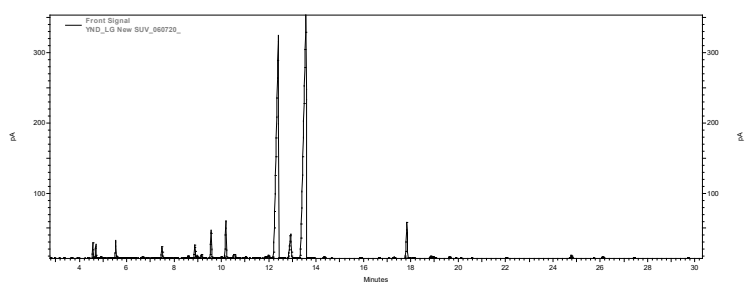

Fig.9. Gas chromatographic profile of the essential oil of cultivar CIM-Suwarna

In the present study, all cultivars met market standards of citral content, but they differ in the level of other essential oil constituents; these variations could be due to the different ratios of geranial and neral ( $\mathrm{G} / \mathrm{N}$ ratio) present in different cultivars of lemongrass (Table 5). $\mathrm{G} / \mathrm{N}$ ratio varies from 1.32-1.84 among the eight lemongrass cultivars examined. There were no notable observations with $\mathrm{G} / \mathrm{N}$ ratio of lemongrass. The $\mathrm{G} / \mathrm{N}$ ratio of $\mathrm{C}$. citratus from Angola is 1.43\% (Soares et al., 2013), in Iran 1.26\% (Avoseh et al., 2015) and whereas in Ivory Coast, it is reported about 1.33\% (Sidibé et al., 2011). The essential oil of lemongrass constitutes generally has more than $45 \%$ of citral. However, the variation in citral content is observed in different species. Whereas $C$. citrates were reported with citral content of 30-94\% being geranial as the major compound (Avoseh et al., 2015).

\section{Correlation of different lemongrass varieties with growth, yield and chemical parameters}

All the growth parameters of lemongrass were positively correlated with theyield of lemongrass (Table 6). Plant height $(0.760 * * *)$, number of leaves per tillers $(0.517 * * *)$ and number of tillers/clump was highly significantly correlated with herbage yield $(0.928 * * *)$. The chemical parameters of lemongrass viz., geranial, neral, geraniol, geranyl acetate and $\mathrm{G} / \mathrm{N}$ ratios were not- significantly correlated with herbage yield of lemongrass. Whereas, a similar trend of results was noticed for oil yield except geranyl acetate $(0.550 * *)$. The herbage and oil yield of lemongrass were negatively non-significant with 
geranial (-0.025\&-0.389), neral (-0.071\&-0.401), and citral (-0.044\&-0.395) respectively. Among the chemical parameter of lemongrass, geranial was highly significantly correlated with neral $(0.993 * * *)$ and citral $(0.999 *)$. G/N ratio was non-significant with all the parameters of the study except with oil recovery $\left(0.455^{*}\right)$ and geraniol $(0.957 * * *)$. The results of the present study are in agreement with the findings of Joy et al. (2006) reported a significant positive association of morphological characters with herbage and essential oil yield of lemongrass. Verma et al.(2015) reported that $\mathrm{G} / \mathrm{N}$ ratio of eight lemongrass cultivars grown in the Himalayan region varied from 1.17 to 1.76 in different seasons.

\section{CONCLUSION}

The performance of lemongrass cultivars in the southern region of Bengaluru, Karnataka, India was similar to that of lemongrass grown in different parts of India in comparison to herbage, oil yield, and quality. The cultivar CIM-Shikar recorded significantly higher amount of essential oil (302.40 kg/ha/year) with a superior market citral percentage of 84.97 $\pm 4.08 \%$. CIM-Atal was superior in geraniol (88.92 $\pm 1.00 \%$ ) compared to citral content among all the cultivars studied; this cultivar may be a partial replacement/substitute for geraniol rich essential oil-bearing plant in the future. Cultivating lemongrass in subtropical and similar climatic areas can offer an alternate cash crop to the farmers, which is not menaced by animals and less maintenance cost void of pests and diseases. This crop can be planted in marginal fertility soils and is also appropriate for wasteland development programmes where, crops establishment and maintenance are difficult.

\section{ACKNOWLEDGEMENTS}

The authors are thankful to the Director, CSIRCentral Institute of Medicinal and Aromatic Plants, Lucknow, India, for his encouragement and required facilities. The present work is supported by Council of Scientific and Industrial Research, New Delhi, India (Aroma Mission, HCP-0007).Institutional publication number CIMAP/PUB/2021/JAN/03.

\section{COMPLIANCE WITH ETHICAL STANDARDS CONFLICT OF INTEREST}

The authors declare that they have no conflict of interest.

\section{REFERENCES}

Allard, R.W., 1960. Principles of Plant Breeding. John Wiley and Sonc Inc., New York, USA.

Anonymous, 1997. Improved clonal variety Krishna of lemongrass developed. Central Institute of Medicinal and Aromatic Plants (CIMAP). Newsletter, 24: 2-3.

Anonymous, 2003. Citral rich and high yielding lemongrass variety 'Nima' released for commercialization.
Central Institute of Medicinal and Aromatic Plants (CIMAP). Newsletter.,1: 4-6.

Anonymous, 2016. New medicinal and aromatic crop varieties. In: MAPs News, CSIR-CIMAP, Lucknow.

Antonioli, G., Fontanella, G., Echeverrigaray, S., Longaray Delamare, A.P., Fernandes Pauletti, G. and T. Barcellos, 2020. Poly (lactic acid) nano capsules containing lemongrass essential oil for postharvest decay control: Invitro and in vivo evaluation against phytopathogenic fungi. FoodChem.,1:326:126997. https://doi. org/10.1016/j.foodchem.(2020).126997.

Avoseh, O., Oyedeji, O., Rungqu, P., Chungag,B.N. and A.Oyedeji.2015. Cymbopogon species; Ethnopharmacology, phytochemistry and pharmacological importance. Molecules.,20: 7438-7453.

Chauhan, N.K., Semwal, M.P., Singh, D., Singh B. and S. Rauthan. 2017. Influence of various plant spacing on growth, herbage yield, essential oil yield and aroma content of palmarosa (Cymbopogon martinii Roxb.) at different harvest under agro-climatic condition of Doon valley. J. Essen. Oil Bearing Plants.,20(6): 1587-1593. https://doi.org/10.1 080/0972060X.2017.1421103.

Francisco, V., Figueirinha, A., Neves, B.M., GarcíaRodríguez, C., Lopes, M.C., Cruz, M.T., and M.T. Batista. 2011. Cymbopogon citratus as source of new and safe anti-inflammatory drugs: bioguided assay using lipopolysaccharide-stimulated macrophages. J. Ethno-pharmacology.,133: 818-827.

Ganjewala, D., Kumari, A. and K.H. Khan. 2008. Ontogenic and developmental changes in essential oil content and compositions in Cymbopogon flexuous cultivars. In: Prasad BN, Lazer Mathew, editor. Recent Advance in Biotechnology. New Delhi, India: Excellndia Publishers. 82-92.

Gupta, B.K. and N.Jain. 1978. Cultivation and utilization of genus aromatic Cymbopogon in India. Indian Perfumer.,22: 55-68.

Hassan, V.U., Saleem, M., Shaffi, N., Din, K.U. and M.Qasuer. 2007. Lemongrass: Botany, Ethnobotany and chemistry. Pak. J. Weed Sci. Res.,13(1-2): 129-134.

Husain, A., 1994. Essential oil-bearing plants and their cultivation. Central Institute of Medicinal and Aromatic Plants (CIMAP) Publication, Lucknow.

Ibrahim, M.M. and K.A. Khalid. 2013. Phenotypic recurrent selection on herb growth yield of citronella grass (Cymbopogon nardus) grown in Egypt, Nusantara bioscience.,5(2): 70- 74.

Joy, P.P., Baby, P.S., Samuel, M., Gracy, M. and J. Ancy. 2006. Lemongrass: The fame of Cochin. Indian J. Arecanut Spices Med. Plants.,8(2): 55-64.

Kumar, S.S., Dwivedi, A.K., Kukreja, J.R. and G.D. Sharma. 2000. Bagchi, Cymbopogon: The aromatic grass monograph. Central Institute of Medicinal and Aromatic Plants (CIMAP) Publication, Lucknow.

Kumari, J., Verma, V., Goyal, A., Shahi, A.K., Sparoo, R., Sangwan, R.S. and G.N.Qazi. 2009. Genetic diversity analysis in Cymbopogon species using 
DNA markers. Plant Omics J.,2(1): 20-29.

Kumari, J., Verma, V., Shahi, A.K., Qazi, G.N. and H.S. Balyan. 2007. Development of simple sequence repeat markers in Cymbopogon species. Planta Medica.,73(3): 262.https://doi. org/10.1055/s-2007-967121.

Kumar, S., Dwivedi, S., Kukreja, A.K., Sharma J.R. and G.D.Bagchi. Cymbopogon: The aromatic grass monograph. Central Institute of Medicinal and Aromatic Plants (CIMAP) Publication, Lucknow (2000).

Kulkarni, R.N., Baskaran, K., Sundaresan, V., ChannayyaHiremath, Yogendra, N.D., Manoj,K.Y., Srinivas, KVN., Kumar, J.K., Kumar, N., Padalia, R.C., Kumar, A., Kalra, A. and A.K. Tripathi.2020. A geraniol rich variety of lemongrass (Cymbopogon flexuosus (Steud.) Wats.): CIM-Atal. J. Med. Arom. PI. Sci.,42(1-2): 64-67.

Lal, R.K., Sharma, J.R., Misra, H.O., Sharma, S. and A.A. Naqvi. 2001. Changes in monoterpene content accompanying development of Cymbopogon winterianusjowittleaves. J. Essent. Oil Res.,13:58162.https://doi.org/10.1080/10412905.1991.9 697955.

Lal, R.K., Misra, H.O., Sharma, J.R., Singh, N., Shasany, A.K., Naqvi, A.A., Bahl, J.R., Prasad, A. and S.P.S.Khanuja. 2006. Citral Rich High Yielding Lemongrass Plant 'Nima' of Cymbopogon flexuosus. United States Plants Patent (PP16712). Council of Scientific and Industrial Research, New Delhi, India, 1-14.

Lal, R.K., Chandra, R., Chauhan, H.S., Misra, H.O., Singh, A., Srikrishna, Shankar, H., Singh, H., Singh, S., Kumar. B., Yadav, A., Shasany, A. K., Dhawan, S. and A. Gupta. 2010. A high yielding variety of lemongrass (Cymbopogonkhasianus) 'CIM-SUWARNA' suitable for water stress/rainfed/marginal land conditions. J. Med. Arom. Pl. Sci.,32: 61-63.

Nair, E.V.G., 1982. Promotional aspect of lemongrass, cultivation and utilization of aromatic plants. CUMAP. Ed. C.K.Atal and B.M. Kapoor, Published by RRL Jammu- Tawi India.

Negrelle, R.R.B. and E.C. Gomes. 2007. Cymbopogon citratus (DC) Stapf: Chemical composition and biological activities. Brazilian J. Med. Biol. Res.,9:80-92.

Padalia, R.C., Verma, R.S., Chanotiya C.S. and A.Yadav. 2011. Chemical fingerprinting of the fragrant volatiles of nineteen Indian cultivars of Cymbopogon Spreng. (Poaceae). Rec. Nat. Prod.,5: 290-29.

Patra, N.K., and B. Kumar. 2005. Improved varieties and genetic research in medicinal and aromatic plants (MAPs). In: Proceedings of Second National Interactive Meet (NIM) on Medicinal and Aromatic Plants, p. 53, Central Institute of Medicinal and AromaticPlants (CIMAP), Lucknow.

Poehlman, J.M. and D.A. Sleper. 1995. Field Crops. lowa State University Press, United States of America.

Rao, B.L., 1997. Scope for development of new cultivars of Cymbopogon as a source of terpene chemicals. In: Supplement to Cultivation and Utilization of
Aromatic Plants. Edits., S.S. Handa and M.K. Kaul, p. 71, National Institute of Science and Communication, New Delhi.

Rao, B.L. and S.N. Sobti. 1991. CKP/25, a hybrid lemongrass. Indian Perfumer. 35: 148-149.

Ravinder, K., Pawan, K., Gaurav, S., Paramjot, K., Gagan, S. and K. Appramdeep. 2010. Pharmacognostical investigation of Cymbopogon citratus (DC) Stapf, Der Pharmacia Letter., 2(2): 181-189.

Sarma, A. and T.C. Sarma. 2005. Studies on the morphological characters and yields of oil and citral of certain lemongrass [Cymbopogon flexuosus (Steud) Wats.] accessions grown under agroclimatic conditions of northeast India. J. Essent. Oil Bearing Plants. 8:250-257.https://doi.org/10.1080/09 72060X.2005.10643454.

Shioda, S. 2014. Recent advances in aromatherapy for dementia. Aroma Research, 15(2): 103107. https://www.cabdirect.org/cabdirect/ abstract/20143204405

Sharma, S.N., Baleshwar and S.C. Taneja. 2005. Growth studies on an elemicin containing grass: Cymbopogan pendulus (Nees ex. Steud) Wats in Jammu, Indian Perfumer. 46(2):105-108.

Sidibe, L., Chalchat, J. C. and R.P. Garry. 2011. Aromatic plants of Mali (IV): Chemical composition of essential oils of Cymbopogon citratus (DC) Stapf and C. giganteus (Hochst.) Chiov. J. Essent. Oil Res.,13(2): 110-112.

Singh, A.L., Rahman, R.S., Verma, R.K., Verma, U.B., Singh, S.K., Singh, A., Chauhanand A.K. Kukreja. 2009. Effect of plant geometry on growth and yield of lemongrass (Cymbopogon flexuosus Ness ex. Stued.) cultivars from Uttarakhand hills. J. Med. Arom. PI. Sci.,31: 10-12.

Singh, O.P. and T.P. Singh. 1999. Genetic variability among some genotype for morphological characters in lemongrass (Cymbopoganflexuosus L. Stapf), Indian Perfumer,43(1): 35-36.

Soares, M.O., Vinha, A.V., Barreira, S.V.P., Coutinho, F., Gonçalves, S.A., Oliveira, M.B.P.P., Pires, P.C. and A. Castro.2013. Cymbopogon citratus EO antimicrobial activity against multi-drug resistant Gram-positive strains and non-albicans-Candida species. In: Méndez-Vilas A (ed.). Microbial Pathogens and Strategies for Combating them: Science, Technology and Education. Formatex Research Center, Spain.

Thappa, R.K., Agrawal, S.G., Dhar, K.C. and C.K.Atal. 1981. Citral containing Cymbopogon species. Indian Perfumer. 25(1), 15-18.

Verma, R.K., Verma, R.S., Chauhan, A. and A.Bisht. 2015. Evaluation of essential oil yield and chemical composition of eight lemongrass (Cymbopogon spp.) cultivars under Himalayan region.https://doi. org/10.1080/10412905.2015.1014936.

Zhang, C., Liu, R., He, J., Ma, Z. and X.Zhang. 2016. Chemical compositions of ligusticum chuanxiong oil and lemongrass oil and their joint action against aphis citricola van der goot (Hemiptera:Aphididae). Molecules,21(10):1359. https://doi.org/10.3390/molecules21101359.

$108|1-3| 8$ 